This PDF is a selection from a published volume from the National Bureau of Economic Research

Volume Title: Measuring and Managing Federal Financial Risk

Volume Author/Editor: Deborah Lucas, editor

Volume Publisher: University of Chicago Press

Volume ISBN: 0-226-49658-9

Volume URL: http://www.nber.org/books/luca07-1

Conference Date: February 8-9, 2007

Publication Date: February 2010

Chapter Title: Housing Policy, Mortgage Policy, and the Federal Housing Administration

Chapter Author: Dwight M. Jaffee, John M. Quigley

Chapter URL: http://www.nber.org/chapters/c3040

Chapter pages in book: $(97-125)$ 


\title{
Housing Policy, Mortgage Policy, and the Federal Housing Administration
}

\author{
Dwight M. Jaffee and John M. Quigley
}

\subsection{Introduction}

Federal policy affecting housing is dominated by indirect and off-budget activities directed toward homeowners - tax expenditure policies and federal credit, insurance, and guarantee programs - rather than the direct provision of housing or the payment of housing allowances to deserving renter households. The implicit goal of increasing homeownership was articulated by the secretary of the Department of Housing and Urban Development (HUD) in 2005, and the federal objective of "an ownership society" has been made quite explicit. ${ }^{1}$ Since 2005, however, there has been a sea change in the mortgage and credit markets; millions of homeowners, particularly lowerincome and first-time homeowners, have been affected. During the fourth quarter of 2008, almost one in ten mortgages in the United States was "in trouble." Delinquencies (i.e., home loans with payments at least thirty days overdue) were 7.9 percent of all outstanding mortgages, and 3.3 percent

Dwight M. Jaffee is the Willis Booth Professor of Banking, Finance, and Real Estate at the University of California, Berkeley. John M. Quigley is the I. Donald Terner Distinguished Professor and professor of economics at the University of California, Berkeley.

Copyright $($ 2 2008, by The Regents of the University of California. Reprinted from the California Management Review, vol. 51, no. 1. By permission of The Regents.

This chapter was originally presented at the NBER conference on Measuring and Managing Financial Risk, Evanston, Illinois, February 2007. A previous and less complete version of this paper, with a somewhat different emphasis, was also distributed as Jaffee and Quigley (2008). In the light of subsequent events, the chapter has been revised extensively, but we have sought to retain as much of the original material as possible. We are grateful for the comments of Deborah Lucas and Susan Wachter and for the research assistance of Claudia Sitgraves.

1. See, for example, "Statement of the Honorable Alphonso Jackson, Secretary, U.S. Department of Housing and Urban Development," before the United States House of Representatives Committee on Financial Services, April 13, 2005. 
of all home mortgages were in foreclosure. (See the National Delinquency Survey of the Mortgage Bankers Association, March 2009.)

This chapter provides a review of the indirect and off-budget activities supporting housing and homeownership, with special emphasis on the mortgage insurance and guarantee programs undertaken by the Federal Housing Administration (FHA). We begin with a brief review of housing subsidy programs, concentrating on the activities of off-budget agencies such as the Federal National Mortgage Association (Fannie Mae), the Federal Home Loan Mortgage Corporation (Freddie Mac), as well as the Veterans Administration (VA) and the FHA. We review the history and operations of these organizations, and we highlight current issues about these institutions and their role in the broader economy. We then concentrate on changes in the role and influence of the FHA, and we consider an expanded role for FHA in a reorganized housing system. We suggest explicit FHA policies designed to protect potential home buyers better from unscrupulous "predatory" lenders, and we suggest that incentives would be improved if many of the activities undertaken by the government sponsored enterprises (GSEs) were assumed by the FHA. This changed emphasis would give a new leadership role to the federal agency that pioneered the long-term self-amortizing mortgage more than a half-century ago.

\subsection{Federal Housing Programs: Direct Expenditures}

As previously noted, federal housing policy is dominated by off-budget programs supporting homeownership and providing subsidies for middleand upper-income homeowners and home purchasers. In contrast, direct federal expenditures for housing programs, those that require Congressional appropriations for housing in the annual budget, are concentrated on programs for lower-income households and mostly for rental households.

Direct federal expenditures on housing began with the Public Housing Act of 1937, a federally financed construction program that sought the "elimination of substandard and other inadequate housing." Dwellings built under the program are financed by the Federal Government but are owned and operated by local housing authorities. Importantly, the rental terms for public housing specified by the Federal Government ensure occupancy by low-income households, currently at rents no greater than 30 percent of their incomes.

This program of government construction of dwellings reserved for occupancy by low-income households was supplemented in the 1960 s by a variety of programs inviting the participation of limited-dividend and nonprofit corporations. Section 8 of the Housing and Community Development Act of 1974 further increased the participation of private for-profit entities in the provision of housing for the poor. The act provided for federal funds for the "new construction or substantial rehabilitation" of dwellings for occupancy by low-income households. The Federal Government entered 
into long-term contracts with for-profit housing developers, guaranteeing a stream of payments of "fair market rents" (FMRs) for the dwellings. Lowincome households paid 25 (now 30) percent of their incomes on rent, and the difference between tenant payments and the contractual rate was made up by direct federal payments to the owners of the properties.

Crucial modifications to housing assistance policy were introduced in the Section 8 housing program. The restriction that subsidies be paid only to owners of new or rehabilitated dwellings was weakened and ultimately removed, and payments were permitted to landlords on behalf of a specific tenant (rather than by a long-term contract with the landlord). This tenantbased assistance program grew into the more flexible voucher program introduced in 1987. Households in possession of vouchers receive the difference between the "fair market rent" in a locality (that is, the HUD-estimated median rent) and 30 percent of their incomes. Households in possession of a voucher may choose to pay more than the fair market rent for any particular dwelling - up to 40 percent of their incomes - making up the difference themselves. They may also pocket the difference if they can rent a HUD-approved dwelling for less than the FMR.

In 1998, legislation made vouchers and certificates "portable," thereby increasing household choice and facilitating movement among regions in response to employment opportunities. Local authorities were also permitted to vary their payment standards from 90 to 110 percent of the FMR. The 1998 legislation renamed the program the Housing Choice Voucher Program; it currently serves about 1.9 million low-income households.

In addition to these programs providing rental assistance, direct appropriations through the HUD also support a few small programs encouraging homeownership: for example, down payment assistance and sweatequity grants.

Direct appropriations under all these programs amounted to $\$ 40.1$ billion in 2009; since 1990, these low-income housing programs have grown hardly at all-by only about 0.5 percent per year in real terms.

\subsection{Tax Expenditures}

\subsubsection{The Federal Tax Code}

The most widely distributed and notoriously expensive subsidy to housing is administered by the US Internal Revenue Service (IRS). Under the tax code, investments in owner-occupied housing have always been treated differently from other investments. If taxpayers invest in other assets (such as equity shares), dividends accruing under the investment are taxed as ordinary income, and profits realized on the sale of the asset are taxed as capital gains. At the same time, the costs of acquiring or maintaining the investment are deductible as ordinary business expenses in computing a taxpayer's net tax liability under the Internal Revenue Code. 
In contrast, if a taxpayer makes an equivalent investment in owneroccupied housing, the annual dividend (i.e., the value of housing services consumed in any year) is exempt from taxation. In addition, the first $\$ 0.5$ million (for married taxpayers) of capital gains realized on the sale is exempt from taxation. Two important components of investment costs, mortgage interest payments (up to $\$ 1.0$ million for married taxpayers) and local property taxes, are considered to be deductible personal expenses. In contrast, depreciation, maintenance, and repair expenses are not deductible.

These benefits have been in effect since the enactment of the Internal Revenue Code. The budgetary costs of the program (i.e., the foregone income tax revenues resulting from these special provisions) are sensitive to monetary policy and tax policy. When interest rates increase, the value of the deduction for interest payments increases. If federal or local tax rates are reduced, the value of the homeowner deduction declines.

The federal tax code also provides two other forms of housing subsidy, both directed to renters rather than homeowners: housing tax credits and tax-exempt bonds.

The Low-Income Housing Tax Credit (LIHTC) Program provides direct subsidies for the construction or acquisition of new or substantially rehabilitated rental housing for occupancy by low-income households. The LIHTC Program permits states to issue federal tax credits that can be used by developers or property owners to offset taxes on other income or that can be sold to outside investors to raise initial development funds for a project. Rents for these dwellings are limited to 30 percent of tenant income, and qualification requires that these units be set aside for occupancy by low-income households for a period of thirty years.

Federal tax credit authority is transmitted to each state, on a per capita basis, for its subsequent distribution to the developers of qualified projects. The credits are provided annually for ten years, so a "dollar" of tax credit authority issued today has a present value of six to eight dollars.

In addition, states have always been permitted to issue debt, and the interest payments made by states (and their local governments) on this debt have been exempt from federal taxation. The Tax Reform Act of 1986 for the first time placed a limit on the volume of bonds that could be issued by states for private purposes. "Private purposes" include the financing of most tax-exempt facilities (e.g., airports), industrial development agencies, student loans, and housing (multifamily construction and homeowner subsidies). The allocation of private-purpose bond authority among these activities is supervised by each state, and the priorities among states may vary substantially.

The subsidy provided by tax-exempt bonds - the net difference between the market interest rate and the rate for tax-exempt paper-varies with changes in federal tax rates and with macroeconomic policy. When interest rates are low and the spread between taxable and tax-exempt interest rates 
is small, state and local governments may choose not to issue tax-exempt bonds, since the costs of issue (underwriting, bond counsel, etc.) are relatively high.

As indicated previously, the magnitude of tax expenditures for owneroccupied housing is dominated by the large and open-ended subsidies provided to those homeowners who itemize their deductions or who sell their residences in any year. Jaffee and Quigley (2007) provide a discussion of the method applied by the Office of Management and Budget for computing tax expenditures. To understand the method, it is useful first to consider the income taxation of commercial real estate as a baseline, since it receives no important or special tax expenditures. The accrued tax liability for an investment in commercial real estate is the sum of the taxes accrued on the net rental income (NR) generated in any year and the tax on the annual capital gain (CG). At a common tax rate on income and gains, $t$,

$$
t(\mathrm{NR}+\mathrm{CG})=t(\mathrm{GR}-\mathrm{MI}-\mathrm{PT}-\mathrm{DRM}+\mathrm{CG}),
$$

where the components of net rental income include the gross rents (GR) minus expenses for mortgage interest paid (MI), property taxes paid (PT), and expenditures for depreciation, repairs, and maintenance (DRM).

In contrast, for owner-occupied residential housing, gross rental income (GR) is not taxable, and capital gains (CG) are essentially untaxed. But depreciation, repairs, and maintenance (DRM) are not deductible. This special treatment creates a "tax expenditure" for owner-occupied residential housing of $t(\mathrm{NR}+\mathrm{MI}+\mathrm{PT}+\mathrm{CG})$. From equation (1), it is apparent that

$$
t(\mathrm{GR}-\mathrm{DRM}+\mathrm{CG})=t(\mathrm{NR}+\mathrm{MI}+\mathrm{PT}+\mathrm{CG}) .
$$

This means that the tax expenditure for residential housing can equally well be computed as the tax benefit arising from permitting net rental income and capital gains to avoid taxation while allowing the deductibility of mortgage interest and property tax payments. (See Quigley [1998] for a discussion.)

For 2007, it is estimated that the exclusion of capital gains on housing from federal taxation cost the Federal Treasury $\$ 34.7$ billion in foregone revenue. (US Office of Management and Budget 2008.) This is almost as much as all direct Congressional appropriations for low-income housing programs. The deduction for homeowners' mortgage payments represents an additional $\$ 100.8$ billion in tax expenditures. The property tax exclusion cost an additional $\$ 16.6$ billion, and the exclusion of imputed net rental income represented another $\$ 7.6$ billion in foregone tax revenues. In contrast, the Low-Income Housing Tax Credit represented only \$5.8 billion in foregone revenues. The issuance of tax-exempt bonds cost about $\$ 1.9$ billion in federal revenue. Overall, federal tax expenditures for homeowners in 2007 were $\$ 182.7$ billion, or about five times the tax expenditures for 
all other housing programs. (See Jaffee and Quigley [2007] for a detailed discussion.)

\subsubsection{Mortgage Credit}

Federal support for housing credit began in the aftermath of the great depression, with the establishment of the Federal Home Loan Bank (FHLB) System in 1932. FHLBs were chartered by Congress to provide short-term loans to retail mortgage institutions to help stabilize mortgage lending in local credit markets. Interest rates on these advances were determined by the low rates at which this government agency, the FHLB board, could borrow in the credit market. In 1938, the Federal National Mortgage Association (FNMA) was established as a government corporation to facilitate a secondary market for mortgages issued under the newly established FHA mortgage program (described next). The willingness of the FNMA to buy these mortgages encouraged private lenders to make FHA, and later VA, loans.

In 1968, the association was reconstituted as a government sponsored enterprise, Fannie Mae. The change allowed Fannie Mae's financial activity to be excluded from the federal budget. Its existing portfolio of governmentinsured mortgages was transferred to a wholly owned government corporation, the newly established Ginnie Mae. In contrast, ownership shares in Fannie Mae were sold and publicly traded. Fannie Mae continued the practice of issuing debt to buy and hold mortgages but focused its operations on the purchase of conventional mortgages neither guaranteed nor insured by the Federal Government. Freddie Mac was chartered as a GSE two years later in 1970, but its shares were not publicly traded until 1989. Originally, Freddie Mac chose not to hold purchased mortgages in its portfolio. Instead, mortgages were pooled, and interests in those pools-mortgage-backed securities (MBS) - were sold to investors with the default risk guaranteed by Freddie Mac.

These mortgages, subject to specific balance limits and underwriting guidelines-referred to as "conforming conventional" mortgages-are securitized by Freddie Mac and Fannie Mae. Until the fall of 2008, these MBS were guaranteed against default risk by the GSEs themselves. (They are now guaranteed by the Federal Government.) The two mortgage GSEs, Fannie Mae and Freddie Mac, operate under Congressionally conferred charters, which provide both benefits and obligations. Their federal charters oblige the GSEs to support the secondary market for residential mortgages, to assist mortgage funding for low- and moderate-income families, and to consider the geographic distribution of mortgage funding, including mortgage finance for underserved parts of urban areas. Their foremost benefit is an implicit US government guarantee of their debt and MBS obligations. This guarantee was reinforced when the two GSEs were placed in a conservatorship in September 2008, an event we return to later.

The GSEs carry out this mission through two distinct business lines: (a) 
they create and guarantee mortgage-backed securities, and (b) they purchase and hold whole mortgages and MBS in their on-balance-sheet retainedmortgage portfolios. The GSEs claim that both business lines are required to meet their charter responsibilities to support the secondary mortgage market and to unify the geographic distribution of mortgage funding. Economists have been quick to point out, however, that the unhedged interest rate risk embedded in the retained-mortgage portfolios creates a large contingent liability for the US Treasury and a systemic risk for US capital markets. Since the GSEs issue MBS, it also seems clear that the retained-mortgage portfolios are not essential for the agencies to carry out their charter obligations.

It is certainly clear that large public subsidies are provided to the GSEs. The more important public subsidy to the GSEs arises from the government's guarantee of all their debt and all their MBS obligations. Other financial institutions would surely be willing to pay a significant fee to receive a comparable guarantee from the Federal Government. This special treatment of the GSEs arose in part because the Federal Government considered the GSEs to be "too big to fail." Alternatively, the Federal Government viewed the securities issued by these organizations as safe and sound-if not, the government would not have exempted the GSEs from the protective regulations governing other similarly situated private entities. Thus, despite an explicit statement in every prospectus disavowing a federal guarantee, the GSEs enjoy lower financing costs than those of similarly situated private firms. $^{2}$

The GSE debt obligations are classified as "agency securities" and have historically been issued at interest yields somewhere between AAA corporate debt and US Treasury obligations. This is despite the fact that even before their losses on subprime mortgages, the firms themselves merited a somewhat lower credit rating. ${ }^{3}$ An estimate of the cost of this implicit federal subsidy for the debt issued by the GSEs can be derived from the spread between the interest rates paid by the GSEs for the debt they issue and the rates paid by comparable private institutions. This comparison, in turn, depends on the credit ratings, maturities, and other features of the bonds issued, as well as market interest rates and credit conditions. Quigley (2006) provides a detailed review of estimates of this spread that have been reported in different studies using different methodologies. On the basis of this kind of evidence, the Congressional Budget Office (CBO 2001) has concluded that the overall funding advantage enjoyed by the GSEs is about 41 basis points.

2. This benefit can be measured either in terms of the subsidized cost of GSE borrowing or in terms of the expected costs that would be imposed on the government if it had to make restitution to GSE bondholders and MBS investors.

3. The Congressional Budget Office estimates that without GSE status, the housing enterprises would have credit ratings between AA and A. See CBO (2001). 
The implicit federal guarantee provides an analogous advantage to GSEissued MBS compared with MBS guaranteed by other private entities. The market requires a greater capital backing for a private guarantee than for a guarantee made by Fannie Mae or Freddie Mac, and the provision of this additional capital reserve is costly to private firms. The CBO (2004) has also estimated that the advantage enjoyed by the GSEs is about 30 basis points. These subsidies could, in principle, either be passed through to mortgage borrowers in the form of lower mortgage rates or be retained as profits by the GSEs. If an equivalent subsidy were provided to a competitive industry, it could be presumed that most, if not all, of the subsidy would be passed through to final consumers. There is evidence, however, that Fannie Mae and Freddie exercise considerable market power (see Hermalin and Jaffee [1996]). However, even duopolists have incentives to pass forward part of a subsidy, and there is evidence that a part—perhaps about half —of this subsidy is passed through by Fannie and Freddie to mortgage borrowers. ${ }^{4}$ The residual fraction of this benefit is retained by the shareholders of the GSEs. This residual arises from the competitive advantage of the GSEs over other financial institutions, which is conferred by their federal charters.

As noted, estimates of the reduction in mortgage interest rates attributable to this subsidy have some range - around, say, 40 basis points (see Quigley [2006] table 3). If the conforming limit for GSE loans were set low enough, more of the benefits of this interest rate reduction would accrue to moderate-income households. But the limit has been set generously by the Federal Housing Finance Board. In 2009, conforming mortgages could be issued for an 80 percent loan on a property selling for $\$ 625,500$ (\$938,250 in Alaska and Hawaii).

Even before being placed in a conservatorship, it was difficult to provide a precise dollar estimate of subsidy provided by federal taxpayers to the GSEs. An up-to-date summary of existing studies is available in chapter 6 in this volume by Lucas and McDonald. Based on the accumulating costs of the GSE conservatorships, it now seems likely that the ultimate cost will be measured in the hundreds of billions of dollars.

\subsection{The FHA and VA Insurance and Guarantee Programs}

\subsubsection{The Great Depression Origins}

Before the Depression of the 1930s, home mortgage instruments were typically of short terms (three to ten years) with loan-to-value (LTV) ratios

4. Differing estimates of the reduction in mortgage rates created by the subsidy has resulted in a quite contentious literature. Perhaps the lowest estimate, 7 basis points, is provided by Federal Reserve economists in Passmore, Sherlund, and Burgess (2005). A much higher estimate is provided by Blinder, Flannery, and Kamihachi (2004) in a study funded and published by Fannie Mae. 
of 60 percent or less. Mortgages were nonamortizing, requiring a balloon payment at the expiration of the term. The onset of the Great Depression engendered a liquidity crisis beginning in 1930, precluding renewal of many outstanding contracts. Other borrowers were simply unable to make regular payments. The liquidity crisis affecting new mortgage loans, together with elevated default rates on existing loans, had catastrophic effects on housing suppliers as well as housing consumers.

Despite voluntary forbearance on the part of some lending institutions and mandated forbearance enacted by many state legislatures, the system of mortgage lending that existed in the early 1930s continued to contract, and many lending institutions simply failed. The establishment of the Home Owners' Loan Corporation in 1933 within the Federal Home Loan Bank System (established a year earlier) provided stop-gap refinancing for a million mortgages. Passage of the National Housing Act of 1934 established the structure of home mortgage insurance and facilitated the growth of the modern system of mortgage finance in the United States.

The 1934 act established the Federal Housing Administration to oversee a program of home mortgage insurance against default. Insurance was funded by the proceeds of a fixed premium charged on unpaid loan balances. These revenues were deposited in Treasury securities and managed as a mutual insurance fund. Significantly, default insurance was offered on "economically sound" self-amortizing mortgages with terms as long as twenty years and with LTV ratios up to 80 percent.

Diffusion of this product across the country required national standardization of underwriting procedures. Appraisals were required, and borrowers' credit histories and financial capacities were reported and evaluated systematically. The modern standardized mortgage was born. ${ }^{5}$

The Mutual Mortgage Insurance Fund, which was established to manage the reserve of annual premiums, was required to be actuarially sound. This was generally understood to involve very small redistributions from highincome to low-income FHA mortgagees. (See, for example, Aaron [1972].) By its original design, the FHA was clearly intended to serve the vast majority of homeowners. Initial loan amounts were restricted to be no larger than $\$ 16,000$ at a time when the median house price was $\$ 5,304 .{ }^{6}$

Near the end of World War II, it was widely feared that the peacetime economy would return the housing market to its Depression-era performance. Indeed, housing starts in 1944 were at about the same level as they had been a decade earlier. The VA loan program, passed as a part of the GI Bill in 1944, rapidly evolved from a temporary "readjustment" program to a long-range housing program available to veterans for a decade or more after

5. See Green and Wachter (2005) for an extensive discussion of this history.

6 . The FHA ceiling was reduced to $\$ 6,000$ in 1938 , but that level was still above the price of the median house at the time, $\$ 5,804$. 
returning to civilian life. This transformation contributed to the boom in the residential construction industry that began in the late 1940s. Ultimately, a liberal program of veterans' home loans was established in 1950 and subsequently extended. In contrast to the insurance provided by the FHA, the VA provided a federal guarantee for up to 60 percent of the face value of a mortgage loan made to an eligible veteran, subject to a legislated maximum. The VA program facilitated loans by private lenders on favorable terms with no down payments at moderate interest rates.

\subsubsection{The FHA and VA Programs in the Postwar Housing Market}

The two programs, FHA and VA, providing government insurance and mortgage guarantees, brought homeownership opportunities to middleclass American households in a short space of time. Figure 5.1 shows the remarkable growth of mortgage originations attributable to these programs. ${ }^{7}$ In 1960, about $\$ 5$ billion in FHA-insured mortgages and $\$ 2$ billion in VA guaranteed mortgages were issued. The programs reached a peak volume in 2003, when the FHA insured about $\$ 165$ billion and the VA guaranteed about $\$ 66$ billion in mortgages. After 2003, the volumes of mortgage originations in both programs declined significantly, so by 2006, the FHA insured under $\$ 54$ billion and the VA guaranteed under $\$ 25$ billion in mortgages, a decline of two-thirds from their peak volumes recorded just three years earlier. However, in the aftermath of the subprime mortgage crisis, the combined mortgage originations of the two government programs rose to just short of $\$ 300$ billion for the year 2008 .

The fraction of total mortgage originations attributable to the FHA and VA also declined systematically over time until the collapse of mortgage markets in 2006. Figure 5.2 reports that the FHA mortgage origination share (based on dollar volume) declined from the peak share of about 25 percent in 1970 to under 2 percent in 2006. The VA guaranteed mortgage share has similarly declined from a peak share of almost 28 percent in 1947 to under 1 percent in 2006. However, in 2008, the share of the two government programs exceeded 20 percent of total mortgage originations, levels not seen for three decades.

The secular decline in the market share of the two programs and the precipitous volatility in both market shares and dollar volumes after 2003 raise serious policy issues for the future of the two programs. A reasoned policy response requires a sound understanding of the forces that contributed to

7. This figure and the subsequent discussion focus on the single-family insurance programs of the FHA and VA agencies. The original mission for the FHA also included multifamily housing, and starting in the 1960s, the FHA multifamily programs became significant in size and scale. Indeed, the multifamily program became quite notorious for allegations of waste, fraud, and corruption; see Vandell (1995) and Quigley (2006). However, multifamily loans never exceeded 15 percent of the total FHA portfolio, and today they are less than 10 percent. In this chapter, we consider only the single-family program. 


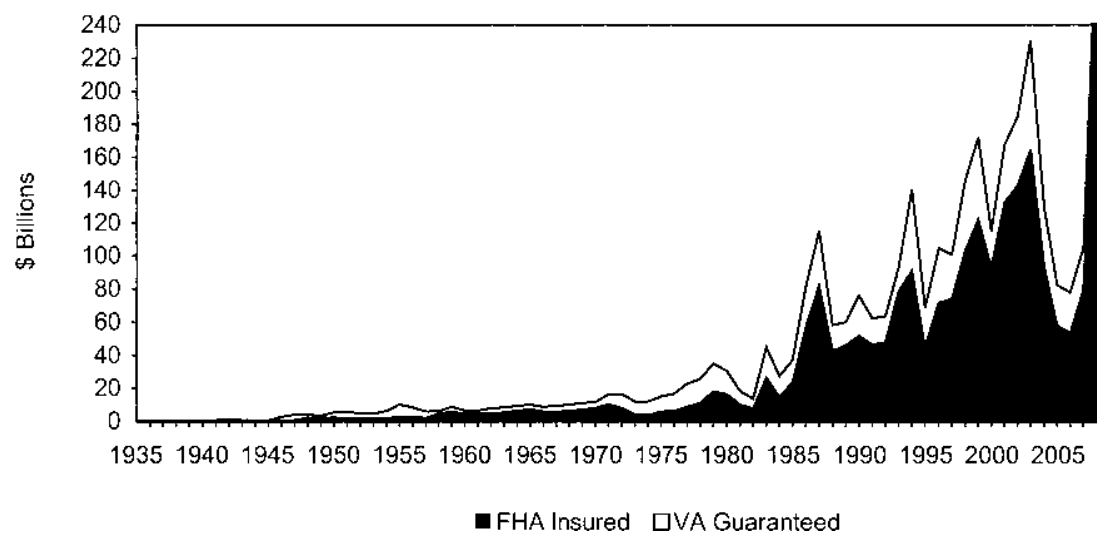

Fig. 5.1 Dollar volume of FHA and VA mortgage originations, 1935 to 2008

Source: Historical Statistics of the United States, Office of Federal Housing Enterprise Oversight (OFHEO), and Inside Mortgage Finance

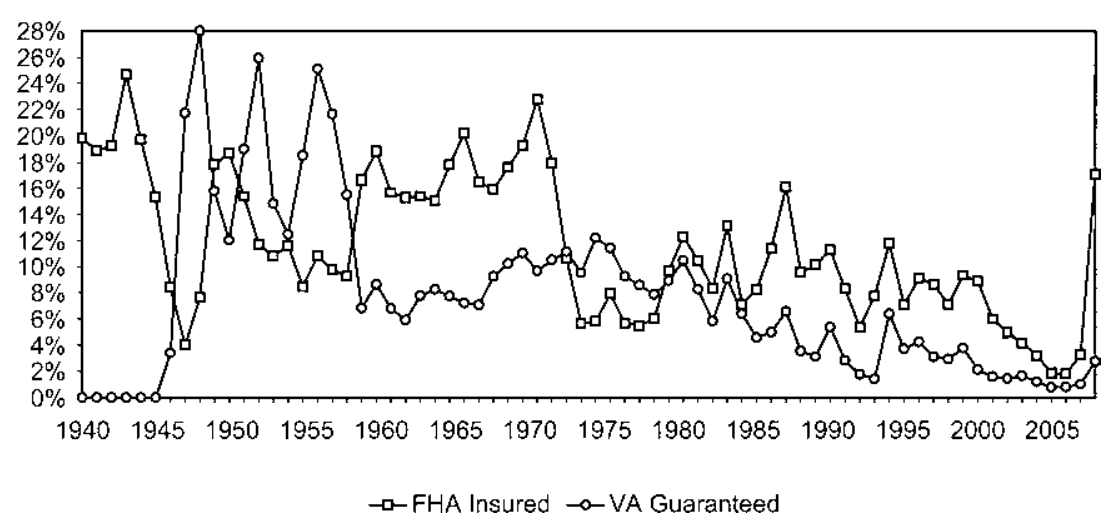

Fig. 5.2 FHA and VA mortgage originations, share of total originations, 1939 to 2008

the secular declines and the recent volatility. We first analyze the long-term factors and then the more recent contributors.

\subsubsection{The Declining FHA and VA Market Shares: Long-Term Causes}

The long-run decline in FHA and VA originations has arisen from two primary factors, both relating to the development of the private mortgage insurance (PMI) industry. A significant PMI industry was first developed in the United States during the housing boom of the 1920s. These insurance firms became insolvent in the early years of the Great Depression, and there were allegations of fraud and mismanagement as well. The creation of a viable PMI industry began in the late 1950s, aided by the evident success of 
the FHA and VA programs. ${ }^{8}$ Until the experience of FHA/VA mortgages was accumulated, it was not well known or widely appreciated just how safe conventional home mortgages were from credit losses. Balances in the FHA Mutual Mortgage Insurance Fund were easily observable to private actors. The development of the PMI industry was also abetted by the expansion of Fannie Mae and Freddie Mac, whose charters require that credit enhancement be provided on all mortgages they purchase or guarantee with LTV ratios above 80 percent. Private mortgage insurance has been the dominant form of this credit enhancement.

Secondly, the rules governing FHA and VA coverage affect the governmentinsured market share as a proportion of the total insured market (that is, the market that includes PMI and other credit enhancements). In particular, fixed-dollar limitations on government-insured mortgages significantly reduced the ability of the FHA and the VA programs to serve middle- and upper-middle-income households. Figure 5.3 reports the volume of FHA and VA insured mortgages as a fraction of all insured mortgages. As the figure shows, the FHA/VA mortgage share declined quite steadily through 2006 but then rose dramatically in 2008 at the onset of the subprime mortgage crisis.

\subsubsection{The Recent Collapse in FHA and VA Program Activity}

Although the FHA program was initially developed to support a large part of the mortgage market, for the past quarter-century, its focus has been on lower-income borrowers. Indeed, the Housing and Community Development Act of 1981 explicitly established specific targets for serving low-income borrowers. The availability of low down payment FHA mortgages and FHA mortgages for those with a less-than-perfect credit rating has meant that the FHA's market share of originations has been larger for those traditionally disadvantaged in the homeownership market. As a result, the overwhelming fraction of FHA borrowers have obtained mortgages with LTV ratios of 95 to 98 percent or more, including a large number of borrowers with "nontraditional" credit histories or with imperfect credit records. The academic literature has documented these specific attributes of the FHA clientele. For example, Ambrose and Pennington-Cross (2000) found that FHA market shares are higher in cities with higher economic risk characteristics, while Ambrose, Pennington-Cross, and Yezer (2002) found that as local economic conditions deteriorate, conventional lenders tend to withdraw mortgage finance, in effect making the government programs the only source of credit.

Data released under the Home Mortgage Disclosure Act (HMDA) include measures of the income and race of borrowers, as well as the census tracts

8. In 1957, the Mortgage Guaranty Insurance Corporation (MGIC) became the first private mortgage guarantee firm established since the Great Depression. 


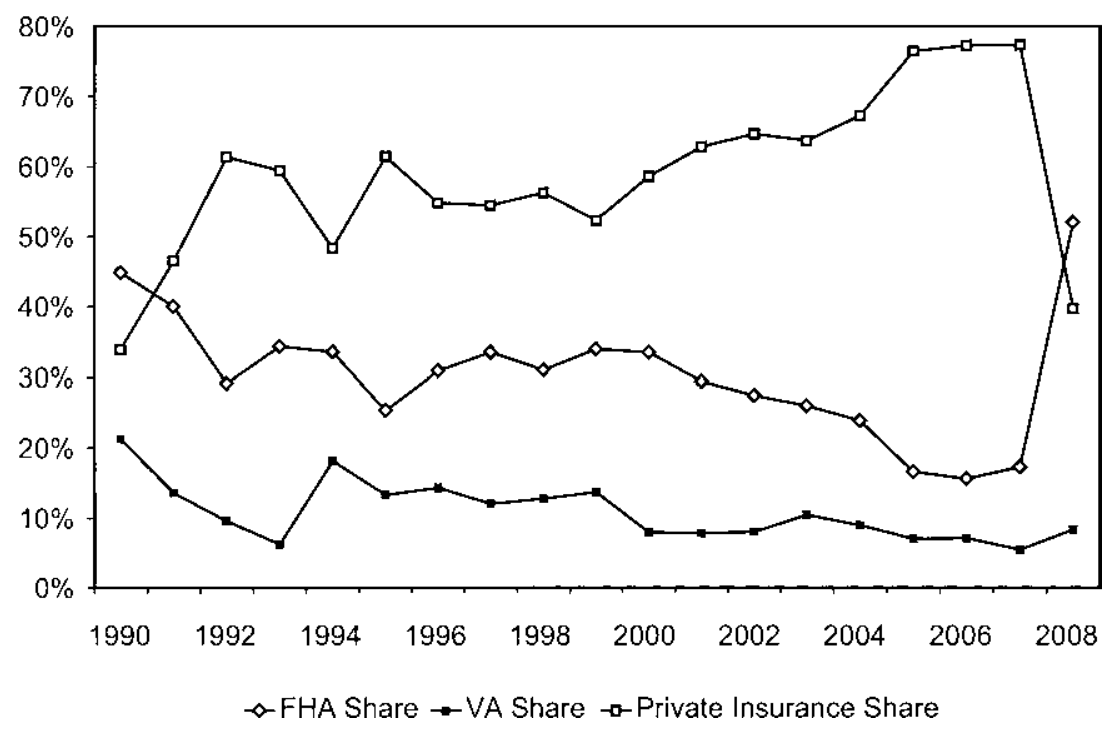

Fig. 5.3 Insured mortgage originations by share of total insured originations

in which they reside. By comparing government-insured and uninsured mortgage originations, it is possible to gauge how well the FHA succeeds in serving a lower-income clientele. ${ }^{9}$ Figure 5.4 presents estimates of the government-insured share of total mortgage originations separately by race. In 1997, market shares for black, Hispanic, and white borrowers were 46, 48, and 20 percent, respectively. By 2005 and 2006, the combined FHA + VA market share for each borrower group had fallen precipitously to between 5 and 10 percent. The data for 2007, the most recent data available, show a distinct recovery for the government programs, especially among black borrowers. This no doubt reflects the recent disruption in conventional subprime mortgage markets. It can be assumed that the detailed 2008 HMDA data will show an even more dramatic recovery in the market share of the government programs.

Figure 5.5 reports the combined FHA + VA market share by the income of the census tract in which the borrower resides. In 1997, the government programs had a 16 percent share of mortgages made in upper-income neighborhoods and close to a 35 percent share of originations in low- and moderate-income neighborhoods. By 2005 and 2006, the FHA+VA share for all neighborhood categories had declined precipitously and converged to values of about 5 percent. More recent data indicate some recovery in circulated, also reports some of these data, but only during the 1996 to 2005 period. 


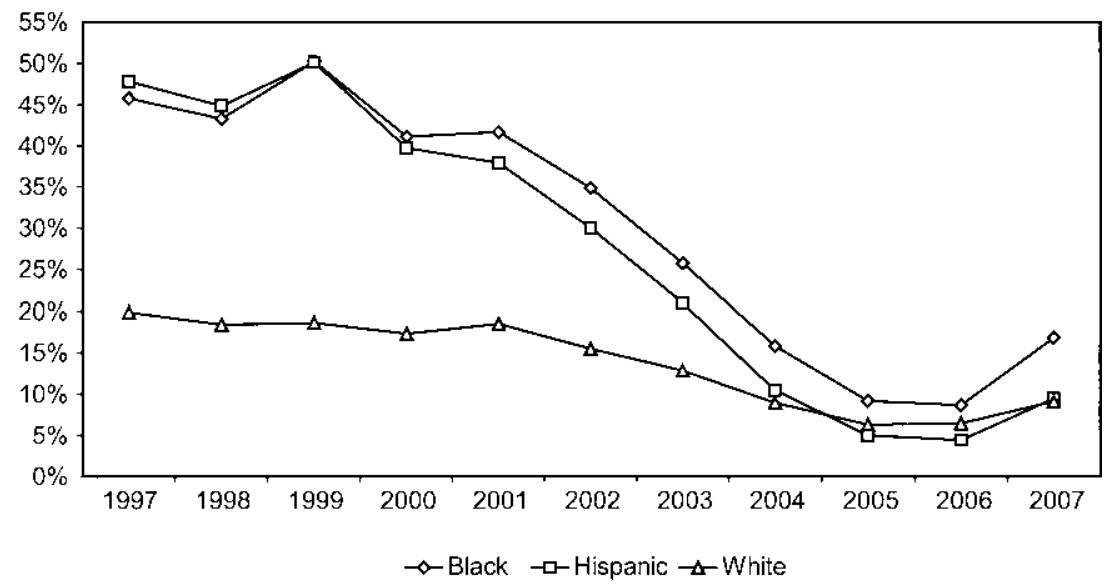

Fig. 5.4 FHA + VA share of origination by borrower race, 1997 to 2007

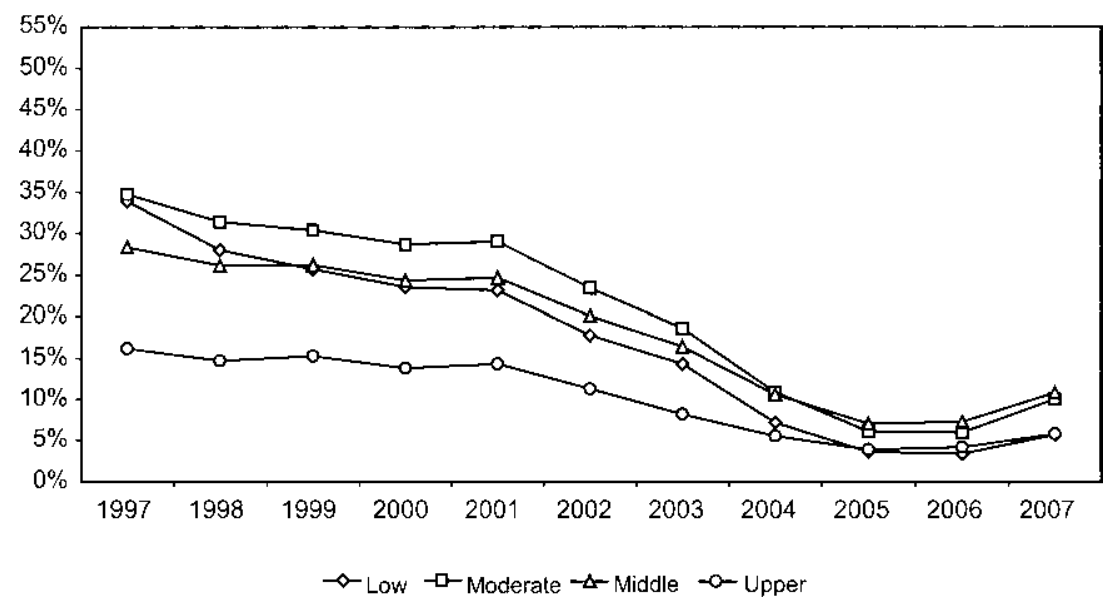

Fig. 5.5 FHA+VA market share by census tract income, 1997 to 2006

the government program share, especially for moderate- and middle-income borrowers.

Figure 5.6 reports analogous FHA + VA market share information by the fraction of minorities living in the census tract of origination. By 2005 and 2006, all these market shares had fallen rapidly to shares of about 5 percent. The data for 2007, in contrast, show a recovery close to a 10 percent market share for the government programs across all census tracts.

In summary, figures 5.4 to 5.6 indicate that however borrower characteristics are categorized, the government-insured share had simply collapsed to a few percent by 2005 and 2006 before recovering somewhat as the subprime mortgage crisis unfolded in 2007. This reinforces the patterns noted previ- 


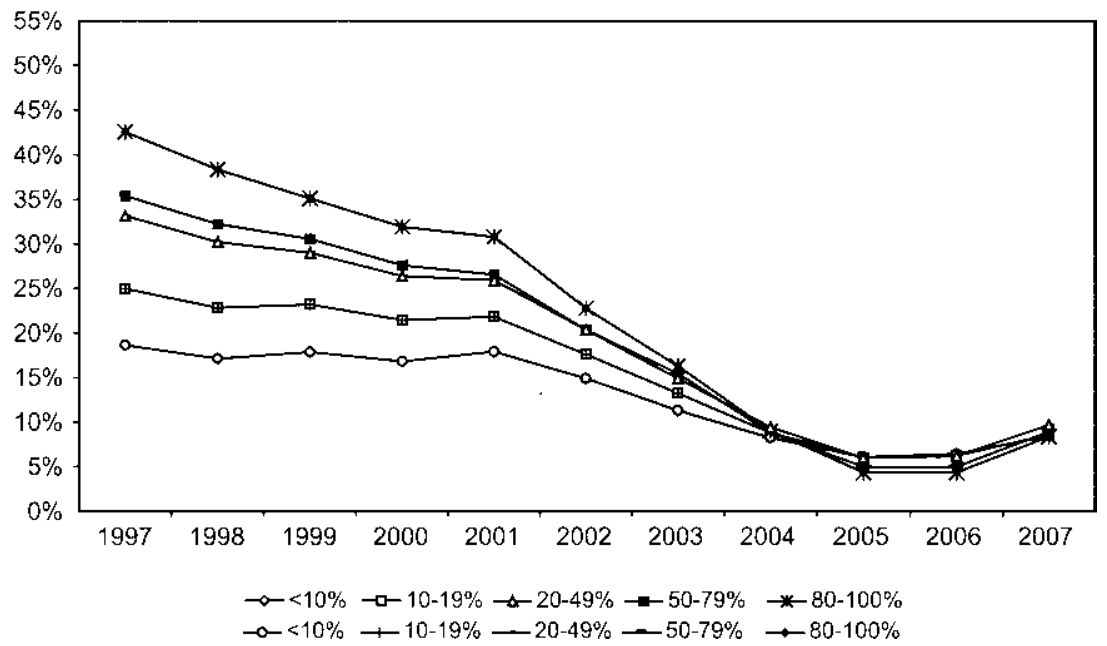

Fig. 5.6 FHA+VA share of originations by census tract percent minority population, 1997 to 2007

ously in figures 5.1 to 5.3, with FHA and VA shares falling precipitously through 2006, then rising steadily through 2007 and $2008 .^{10}$

We now consider the factors responsible for this precipitous decline in FHA and VA originations from 2003 through 2006. We identify four specific factors: subprime lending, predatory lending, GSE competition, and the failure of the FHA to innovate its mortgage contracts. We discuss each in turn.

\section{Subprime Lending}

Figure 5.7 shows the dramatic inroads that conventional subprime lending made as a share of total home mortgage originations. ${ }^{11}$ As recently as 2002, subprime lending represented only 7 percent of total mortgage originations, but its market share peaked at more than 21 percent by 2006 . This 14 percentage point increase in market share coincides with the precipitous decline in FHA and VA lending. Correlation, of course, need not imply causation. But the subprime lenders and the government-insured lending programs share a very similar clientele-focusing on borrowers with lower credit scores, offering lower down payments, and so on. So, it

10. The aggregate data use the HUD's estimates of total mortgage originations and FHA and VA mortgage originations based on information reported by the agencies. The HMDA data, in contrast, are based on a sample of large, for-profit, and metropolitan lenders who are required to report their loan applications and loans awarded. The higher FHA+VA market share in the HMDA data arises if the surveyed lenders have a higher share of governmentinsured mortgages than the universe of all lenders.

11. See Murphy (2007) for a useful primer on subprime mortgages. 


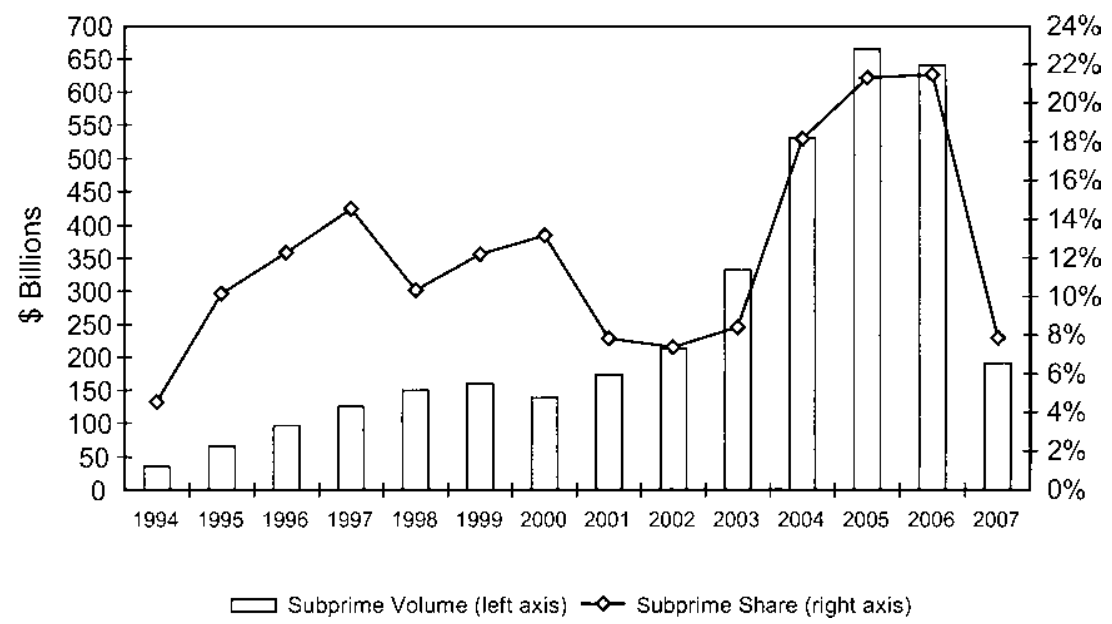

Fig. 5.7 Subprime lending and total mortgage originations

seems highly plausible that the expansion of the subprime loan market is the source of most of the decline in the market share of the FHA and VA programs.

The great financial distress of some subprime borrowers has been reflected in rising foreclosure rates on these mortgages. Figure 5.8 compares the foreclosure rates on FHA, VA, and conventional mortgages in recent years, based on data from the Mortgage Bankers' Association (MBA). Prior to 1998, the annual default rates for the available categories never reached as high as 2 percent. In contrast, the foreclosure rates on subprime loans, with data starting in 1998, are almost an order of magnitude higher, exceeding 9 percent annually in 2001 and approaching 14 percent of year-end 2008. In recent years, the FHA foreclosure rate has remained moderately high, above 2 percent, while the VA foreclosure rate has remained above 1 percent. The foreclosure rate on prime conventional loans, stable for many years, is approaching 2.0 percent by year-end 2008 .

The growth of the subprime loan market was certainly one source of the recent decline in the FHA and VA market shares. But this raises the deeper question of why the subprime market expanded so suddenly. What skills or techniques were subprime lenders able to adopt - quite suddenly, it appears, in about 2000 - that were not evident earlier? This is a key question for the government-insured programs, since it may identify the missing skill or technique that could allow them to regain a reasonable share of the lowerincome mortgage market on a sustained basis. Given the relatively short history of the subprime market and the uncertainty over how (or whether) it will survive its current crisis, answers are necessarily speculative. Nevertheless, three factors appear to be crucial: 


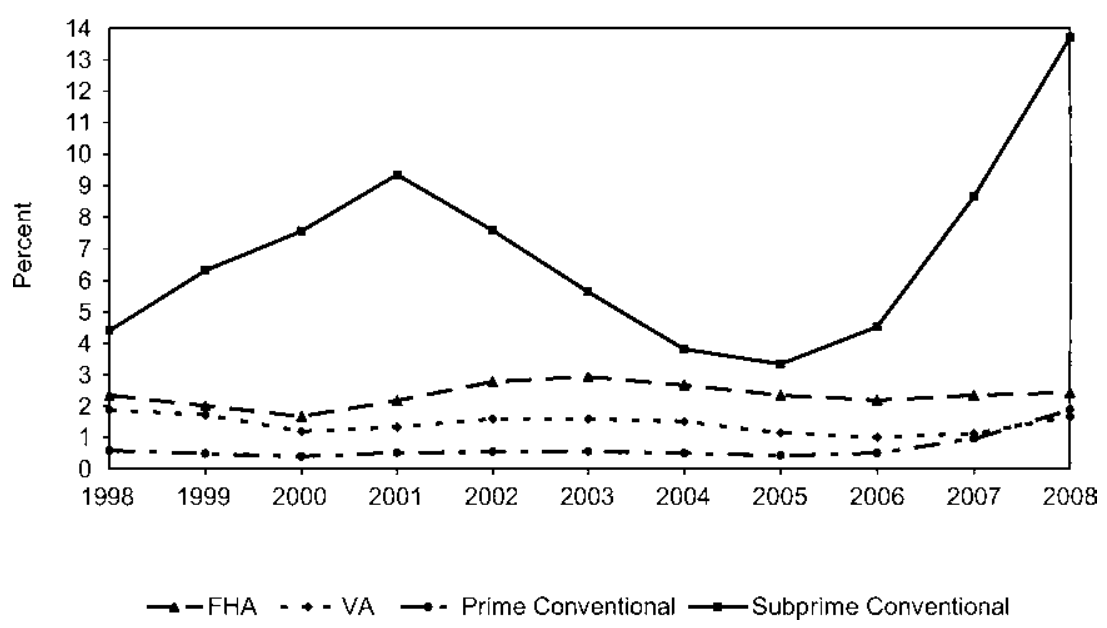

Fig. 5.8 Foreclosure rate, year-end inventory

1. Technology. Access to large bodies of information concerning current borrowers and past loan outcomes has been combined with computing power and statistical methods to extract useful information concerning likely default rates and loan costs, especially for lower-quality borrowers.

2. Contract innovation. The subprime mortgage markets created new "alternative" mortgage contracts (including interest-only, optional-payment, and incomplete-document loans). ${ }^{12}$ They have also expanded the use of traditional formats (such as adjustable-rate and negative-amortization mortgages) as alternatives to the standard, fixed-rate, long-term mortgages offered by FHA and VA.

3. Securitization. Many of the lenders utilizing this new technology and sponsoring innovative contracts have a limited capacity to hold mortgages, so it has been essential they have access to the new and efficient techniques of mortgage-backed and asset-backed securitization for selling newly originated loans in the secondary market.

Although these factors that created the subprime mortgage boom and crisis are reasonably clear (see, for example, Quigley [2008]), it is very unclear how the mortgage market will be restructured in the aftermath of the crisis. The FHA and VA markets clearly received renewed demand during 2007 and 2008 as the subprime market crashed. In the longer run, however, the market for alternative mortgages does rest on some sensible fundamentalstechnology, contract design, and securitization - so it is an interesting ques- 
tion of whether that market will continue to operate in some form as a viable competitor for the FHA and VA government insurance programs. We will return to this issue when discussing the future of government insurance programs in section 5.5.

\section{Predatory Lending}

Headlines in the business press as well as the popular press have drawn attention to predatory lending practices as well as subprime mortgages. Predatory loans generally refer to loans that the borrower would have rejected with full knowledge and understanding of their terms as well as those of available alternatives. In practice, predatory loans rely on a range of practices including deception, fraud, and manipulation that create loans with terms that are highly disadvantageous to the borrower, thus creating a high likelihood of default (to which the lender is generally immune; see Government Accountability Office [GAO] 2004 and Morgan [2007]). ${ }^{13}$ The two key features of predatory loans are as follows: first, the borrower would not have agreed to the loan had he or she understood the terms and conditions; and second, the lender or investor earns an acceptable return, even if the borrower defaults. These features contrast with other conventional or alternative loans in which the borrower benefits from the loan and in which the lender (or loan investor) suffers a loss if the borrower defaults.

In July 2008, the Federal Reserve issued important additions to the Truth in Lending Act (TILA), and the HUD has prepared parallel changes in the rules implementing the Real Estate Settlement Procedures Act. The key component of the TILA reform is a suitability requirement that requires lenders on subprime mortgages (after October 1, 2009) to verify that the borrower is capable of making mortgage payments at the highest level the mortgage contract can require. There are also restrictions on "teaser rates," low- or no-documentation loans, and prepayment penalties. ${ }^{14}$ In addition, subprime mortgages now require certified house value appraisals. Had those requirements been in effect earlier, predatory lending would have been reduced, and quite possibly, the subprime mortgage crisis would have been less severe.

Another useful regulatory approach would focus on disclosures and incentives that can mitigate the informational asymmetry under which inexperienced borrowers are unaware of more beneficial alternative contracts for which they may also qualify. For example, mortgage brokers often receive their full commission soon after a loan is closed. If the loan subsequently

13. Specific devices include loan flipping (repeated refinancing with excessive prepayment penalties), unexpected balloon payments, and mandatory arbitration.

14. In the original 2007 version of this chapter, we emphasized the importance of a suitability requirement to eliminate future predatory lending, as well as prohibitions against teaser rates and low-documentation loans and limitations on prepayment penalties. 
defaults, there is no recourse to the broker for the commission already paid. Mortgage brokers thus have some incentive to recommend loans to borrowers, even when they suspect that the default probability is high. An incentivecompatible reform would impose a delay on the payment of origination fees and commissions to mortgage brokers, at least until the borrower creates a credible record of on-time payments. More generally, it would seem that the best way to mitigate asymmetric information is to create a standardized, nonpredatory, alternative loan and to require that all lenders making loans to lower-income borrowers disclose the availability of this loan. As noted next, this could be an important function of an expanded FHA.

\section{The Government Sponsored Enterprises Go "Down Market"}

The expansion of the GSE mortgage portfolios into riskier mortgages is a third important factor that reduced the market share of the FHA and VA government insurance programs. The GSE expansion was partly profit motivated, since the GSEs required new markets if they were to expand beyond their traditional domain of prime-conforming mortgages. But it was also regulatory based, since the GSEs faced "affordable housing goals," which required that they allocate specified shares of their lending activity to various classes of lower-income borrowers. (See Weicher [2006] and Jaffee and Quigley [2007] for detailed discussions of the goals.)

The academic literature has confirmed the "down-market" expansion of the GSEs and has found it to have a measurable impact on the traditional domain of the government-insured programs. An and Bostic (2008) presented quantitative evidence that the GSEs are increasingly targeting borrowers who would otherwise represent the higher-quality segment of FHA borrowers. Using HMDA data, they confirmed the fact that as the GSE share of originations in an underserved neighborhood expands, the FHA share declines. Their theoretical model also predicts that in response to GSE competition, the FHA will raise its underwriting standards in order to control what is now a lower-quality loan pool, on average. Most recently, An et al. (2007) have investigated the relationship between the GSE affordable housing goals and the FHA clientele. Using a sample of FHA loans, they confirmed the decline in the quality of the FHA borrowing pool. They also found that FHA borrowers exercise their refinancing options less aggressively, consistent with other studies of lower-income borrowers and those with lower credit ratings.

Analyses of the "overlap" in clientele also help measure the possible substitution between GSE and FHA loans. The HUD has commissioned several studies of this overlap, including a thorough analysis by Abt Associates (HUD 2005). The Abt analysts used microdata on borrowers and their loans to estimate two statistical models: one predicting the choice of an FHA loan and the other predicting borrower choice of a GSE loan. If the 95 percent confidence interval for an individual loan did not include a probability of 0.0 
or 1.0 for either the FHA or the GSE category, then the loan was characterized as an "overlap." Based on data from 1998 to 2000, HUD (2005) found that 10 to 14 percent of the loans made by FHA fell in the "overlap" region. This result is consistent with the academic studies documenting substitution between the FHA and GSE loans. The quantitative estimate does indicate that no more than 14 percent of the FHA clients would also qualify for GSE loans. However, the HUD analysis was based on data from 1998 to 2000. As the GSEs have lowered their underwriting standards since then, the degree of overlap has greatly expanded.

\section{Failures in Contract Innovation and in Underwriting at the FHA}

The previous sections indicate how subprime, predatory, and GSE lenders have greatly reduced the market share of FHA and VA loans in recent years. It is natural to ask why the government programs have not responded with innovative contracts and underwriting methods of their own in order to protect their market share. Indeed, historically, the FHA was responsible for crucial innovations in the US mortgage market: the fixed-payment, long-term, fully amortizing mortgage in the 1930s and the first mortgage-backed securitization program-Ginnie Mae-in the 1970s. In recent years, however, the FHA has shown a distinct disinclination to innovate.

In particular, the FHA has offered no response to the new alternative mortgages created as part of the subprime market. At least in principle, the FHA could have created better-designed mortgages that would have mitigated or even averted the major losses. One major handicap is the FHA's outdated credit scoring model, which suggests that the FHA cannot adequately judge the quality of borrowers or loans, nor can it implement risk-based pricing by charging higher insurance fees on demonstrably riskier mortgages (see GAO [2006a]). Given that most of the recent mortgage innovations have involved somewhat riskier contracts, it is essential that these risks be reflected in the insurance premiums (unless a subsidy to riskier borrowers is an explicit policy). To be sure, the FHA requires Congressional approval before it can carry out these and related innovations. Mobilizing Congress to act is a time-consuming friction at the least, one that surely inhibits the innovative process (see Weicher [2006]).

There is also a sense that the failure of the FHA to innovate reflects to some degree the agency's philosophy. This is suggested in the report commissioned by the HUD in 1995, at a time when the FHA was facing an earlier crisis concerning its future. A major part of that report argues that the FHA clientele is "unique," with no significant overlap with either private mortgage insurance or the GSEs. The report dismisses what were the early signs that the conventional mortgage market was making headway in meeting the needs of underserved borrowers: 
Only FHA allows for a combination of credit histories, cash balances, downpayments and payment ratios, which provide mortgage credit opportunities to families with past credit problems and broken income streams. Because of this, private market initiatives will grow as they attract new homeowners, but they will not significantly diminish the core business of FHA. (HUD 1995, 7-2)

A bit later, the report lists some "distinctive" FHA benefits: up to full financing of up-front loan closing costs and insurance premiums, lower down payment requirements on both home purchase and refinancing loans, higher allowances for seller-paid closing costs, and greater protections against foreclosure.

These FHA "benefits" are hardly distinctive, and they are certainly not unique.

The FHA has also resisted implementation of risk-based pricing for its insurance premiums. From its inception in 1934 through 1983, the FHA charged a flat annual insurance premium of 0.5 percent on the outstanding loan balance - very low by current standards. In 1983, the FHA switched to a 3.8 percent, one-time, up-front fee that was revenue neutral overall compared to the earlier system. As a result of worsening underwriting experience during the 1980s, the 1990 National Affordable Housing Act (NAHA) required an increase in the FHA premiums and for the first time imposed higher premiums on loans with higher LTV ratios. However, in practice, this component of risk-based pricing was quantitatively minor. The major consequence of changes mandated by the NAHA was that for the first time, FHA premiums became significantly higher than the PMI premiums a borrower would pay if he or she qualified for both insurance programs. Since rational borrowers who are eligible for both FHA and PMI loans would always choose the lower-cost PMI option, the FHA argues that at least in principle, there is no effective overlap between the FHA and PMI clientele.

In summary, it appears that two of the three forces that lead to the dramatic growth in subprime lending, technology and contract innovation, are missing — seemingly intentionally missing — from the current FHA strategic plan. Furthermore, even the third factor, securitization, for which the FHA was once the leader with its Ginnie Mae program, is at risk for the first time. The Ginnie Mae program will not able to maintain a liquid market for its mortgage-backed securities unless its supply of raw material-newly originated FHA and VA mortgages - were to expand.

\subsubsection{FHA Single-Family Program Subsidies}

The mortgage insurance fund for FHA's single-family housing insurance program has remained solvent continuously, and with the exception of a few brief intervals, the fund has remained actuarially sound as well. The 
FHA has also reported under the budget accounting rules specified in the Federal Credit Reform Act of 1990 (FCRA) that the program provides a net surplus to the government; that is, the program is estimated to provide a negative subsidy to general taxpayers - as much as $\$ 1.5$ billion during fiscal year 2003. This is an important factor, because the FHA is a "discretionary" program and otherwise would require an annual appropriation for any explicit subsidy costs.

The Congressional Budget Office, however, has challenged the FCRA method and contends that the Mutual Mortgage Insurance program actually requires a positive federal subsidy when the actuarial costs are computed appropriately (see CBO [2003] and [2006]). There are two main elements of contention. The first element is that the FCRA method excludes administrative expenses from the subsidy computation. Indeed, were administrative costs included, the FCRA method indicates that the FHA received a modest subsidy from federal taxpayers in fiscal year 2007.

The second element is that expected future losses from insurance activity are computed as a single average present value under the FCRA method. This ignores the dispersion of possible losses, including the likelihood that the greatest losses will occur when the economy is in a recession. The CBO contends that the covariation of potential realized losses and weak states of the overall economy requires that a "risk premium" be added to the computation. The CBO quantifies this risk premium as the difference between the insurance premiums charged by the private mortgage insurance industry and the premiums charged by the FHA on comparable mortgages. Using this benchmark, the $\mathrm{CBO}$ estimates that the FHA program actually received a taxpayer subsidy of about $\$ 2$ billion for fiscal year 2007 (compared to the small surplus computed using the FCRA method).

The FHA disagrees with the principle behind the CBO's risk premium adjustment. In the FHA view, the federal guarantee that backs its insurance and the FHA's privilege to borrow from the US Treasury at risk-free interest rates are fundamental features of the program, which allow the FHA to operate with vastly lower capital ratios than its PMI competitors. The quid pro quo is that the FHA program serves a much riskier clientele. In the FHA view, an accurate actuarial computation of its expected losses relative to the premiums charged is the proper basis for determining the cost, if any, that the program imposes on the federal budget.

The proper computation of the program's subsidy is important if Congress is to make sensible appropriations for the FHA programs in comparison with all other discretionary government expenditures and also in the evaluation of alternative means for subsidizing housing (for example, in comparing HUD voucher programs and FHA mortgage insurance). A proper computation of the subsidy amount would also help to avoid unexpected and quite unpleasant budgetary surprises, which 
may occur when any insurance program suddenly suffers losses that exceed its revenues. ${ }^{15}$

\subsection{Options for the FHA Single-Family Insurance Program}

The large decline in the volume of FHA and VA mortgage originations between 2003 and 2006 raises fundamental questions about the future of the agencies. The plummeting share of FHA and VA in total originations led to suggestions that the agencies simply be closed. This action would have recognized the apparent success of private mortgage insurance in insuring risky mortgages. Thus, while the FHA programs may have increased homeownership historically among the eligible population, ${ }^{16}$ the elimination of the FHA might simply induce private lenders to be more aggressive in supplying credit to this segment of the market. The crash of subprime lending since 2007 has, of course, provided new life to the FHA and VA programs. There remains, however, the long-term question of what the proper role will be for the government programs as a restructured mortgage market emerges in the aftermath of the subprime crisis.

\subsubsection{An Expanded Role for the FHA with Alternative Mortgages and Risk-Based Pricing}

One approach would allow the FHA to continue to function in its historical manner, but to require that it become much more aggressive in using technology to improve its underwriting policies for higher-risk borrowers, and to incorporate risk-based pricing in federal mortgage products. This would entail an expanded legislative mandate for the agency, increasing loan limits, eliminating statutory down-payment requirements, and encouraging riskbased pricing of mortgage products. These directions have been endorsed by the various interest groups that would benefit from more robust and liquid housing markets. ${ }^{17}$ However, concerns have also been raised that the FHA will not have the expertise to manage a more creative underwriting program

15. As a case in point, Congress recently had to appropriate more than $\$ 20$ billion to the Federal Flood Insurance (FFI) program to cover the unexpected losses created by Hurricane Katrina, an amount equal to the total insurance premiums, net of administrative expenses, collected since that program's inception in 1968; see Government Accounting Office (2006b). In other words, the premiums charged over the program's forty-year history actually represented more than a 50 percent subsidy. This subsidy had gone unrecognized, because the program had broken even on a cash flow basis over its entire history until the 2005 hurricane. But this represented only good luck; no previous flood had struck a major metropolitan center-hardly the basis for sensible actuarial budgeting.

16. See Quigley (2006) for a further discussion of the dramatic effect of the FHA program in expanding homeownership among its clientele households.

17. Some of these measures have been introduced into legislation (e.g., the "Expanding American Homeownership Act," H.R. 1752, and H.R. 5121) and have been debated in the House of Representatives but not in the Senate. 
entailing more complicated and riskier loans, and that risk-based pricing will eliminate what some consider the current beneficial pattern of crosssubsidization of riskier borrowers by safer borrowers (See GAO [2007b] and Inside Mortgage Finance [2007a, 2007b]).

\subsubsection{Demonstrable FHA Alternative to Predatory and Subprime Loans}

An alternative approach, not inconsistent with the preceding proposal, is to expand the role of the FHA by focusing on its potential to mitigate predatory lending. As previously noted, the July 2008 Federal Reserve expansion of the Truth in Lending regulations is a major step forward. These regulations, if enforced, will no doubt reduce the extent of predatory lending, but it is equally clear that they would also reduce the incidence of alternative mortgages that are beneficial to borrowers and lenders.

Arguably, the operation of a "fully competitive" market could itself protect less informed market participants. However, the wide range of consumer protection legislation enacted in the United States suggests that policymakers are frequently not confident that competitive markets can be depended on to perform this role. Even within the financial markets, the US government has historically taken vigorous action to protect consumers. For example, in stock market trading, the SEC regulates brokers and mutual funds, requiring them to obtain "best execution" for their customers, even though, at least in principle, "perfect competition" would achieve the same end. Similarly, brokers are held to a "suitability" standard by the National Association of Securities Dealers (NASD) in mediating retail stock transactions. Government intervention in these ways no doubt reflects some paternalism, but as Sunstein and Thaler (2003) argue, financial decisions by consumers often reflect framing and other behavioral factors, with the result that an element of low-cost paternalism might be judged to be highly beneficial overall.

Consumer protection has also long been a rationale for housing and mortgage market legislation (see US Department of Treasury [2000]). For example, the Truth in Lending Act (Regulation $\mathrm{Z}$ of the Federal Reserve Act) has long specified very precisely how the terms of installment loans, including mortgage loans, must be disclosed to borrowers. For another example, the Real Estate Settlement Procedures Act (RESPA) regulates the behavior of the parties to a home purchase transaction and specifies in detail the disclosures required by lenders to borrowers. Finally, the Home Owner and Equity Protection Act (HOEPA) requires special disclosures concerning prepayment penalties, balloon payments, and negative amortization on certain refinancings and home equity loans.

These detailed regulations illustrate the fact that Congress has not been shy to take a paternalistic stance when it felt poorly informed borrowers were disadvantaged. It appears that the details of modern mortgage contracts 
are sufficiently technical and specialized that it is more efficient to regulate predatory lending with specific legislation.

An aggressive and innovative loan demonstration by the FHA can be an efficient and effective means to reverse the inroads that predatory lenders had achieved as a result of the inherently complex nature of the new mortgage contracts. Suppose, for example, legislation enabled the FHA to offer risk-based pricing and adjustable rate mortgages, and at the same time, the FHA was directed to develop new alternative mortgage contracts that would offer competitive terms to those currently eligible for FHA financing but who had previously been attracted to the private subprime market and at least in some instances by predatory lenders.

Disclosures concerning these new alternative FHA mortgages could be of potential value in deterring predatory lending to lower-income home purchasers. Comparable actions by government entities can be found in other markets. The student loan market provides some comparison, but the Direct Loan Program provided through the US Department of Education does not compete head-to-head with loans offered by banks and other private lenders. ${ }^{18}$ A more appropriate example at the federal level is the United States Postal Service, which provides mailing services that compete with private suppliers such as Federal Express and the United Parcel Service. And at the state level, the Departments of Insurance in a number of states provide comprehensive information on the auto insurance and homeowner insurance options available to consumers based on the rate filings of their registered insurers. ${ }^{19}$

To apply this technique to the subprime mortgage market, the FHA would have to offer a borrower one or more alternative mortgages for consideration well in advance of a scheduled house closing. To allow the FHA to prepare these loan offers, information about borrower credit worthiness, assets, home appraisal, and so on would have to be transmitted to the FHA in advance of a contemplated mortgage transaction by any lender about to make a loan to a household eligible for FHA financing. The concept of requiring lenders to make unique disclosures prior to a loan is already a core component of the HOEPA. The FHA would be directed to use this information to produce one

18. The federal student loan programs operate in two forms. The Direct Loan programs use government funds, and the loans are originated and serviced by the US Department of Education. The Federal Family Education Loan (FFEL) programs use funds provided by a bank or other participating lender, but the loans are government guaranteed, and the key loan terms, including the interest rate, are identical to the Direct Loan programs. Both of these programs compete with fully private market loans that are available from banks and other lenders. Private market student loans, in turn, come in different versions, including those where the student is "certified" by his or her university versus loans that do not require such certification.

19. For example, in California, auto insurance premiums are regularly published by the state government. See http://interactive.web.insurance.ca.gov/survey/survey?type=autoSurvey \&event $=$ autoSearch. For Berkeley, California, for example, the highest rates reported for standard coverage are more than double the lowest rates. 
or more specific loans for consideration by the contracting household. These terms would be transmitted to the household in a side-by-side comparison with those offered by the subprime lender. Mortgage contracts would not be enforceable unless the contracting household had explicitly declined the terms of an FHA mortgage in favor of a loan supplied in the private market. This requirement, together with the suitability rules described earlier, patterned after those of the NASD, could provide powerful deterrents to predatory lending.

These disclosure requirements would provide the borrower with an explicit alternative in the form of an available FHA loan, as well as the full set of information suggested by Congress:

This new disclosure should include a table clearly displaying a full payment schedule over the life of the loan, all fees associated with the loan, an explanation of the "alternative features" of the loan (i.e. negative amortization) and a full explanation of the risks associating with taking advantage of those features, including the timeframe in which borrowers were likely to feel the negative effects of those risks. (Joint Economic Committee 2007, p. 18)

Implementation would require FHA-eligible households to consider and reject the terms of competitive FHA mortgages before contracting for alternative mortgage finance in the private market. In making this decision, borrowers would have the full set of mortgage information, and they would have a specific alternative to consider. If, after consideration of the terms proffered, a household chose alternative mortgage finance, it would not be on the basis of incomplete information or the misrepresentation of alternatives. This is probably the best one can hope for in guiding the choices of others in a market economy.

\subsubsection{Merging the GSE Activities into the FHA/Government National Mortgage Association (GNMA) Nexus}

Finally, the breakdown in the mortgage markets following the subprime crisis might provide the opportunity to reposition the primary mortgage securitization business of the GSEs within a government entity. This activity could be operated inside the HUD as a middle-income mortgage guarantee business, parallel to the FHA and GNMA; see Jaffee (2009a, 2009b). Alternatively, this securitization activity could be operated as a new government-owned corporation, which could provide more flexibility. The exemplary history of the FHA provides a basis for believing that the business of guaranteeing and securitizing mortgages - in particular, relatively highquality mortgages - could be efficiently carried out by a government entity, especially if it were afforded the flexibility inherent in a government-owned corporation. The key benefit, in the context of the subprime mortgage crisis, is that the new program would provide a strong government safety net 
against current and future systemic market failures. We should expect that major innovations in mortgage finance would arise and be carried out in the private mortgage markets. Thus, it would be critical that any new government programs not be subsidized so that they would not crowd out efficient private market initiatives.

\section{References}

Aaron, H. J. 1972. Shelter and subsidies: Who benefits from Federal housing programs? Washington, DC: Brookings Institution.

Ambrose, B., and A. Pennington-Cross. 2000. Local economic risk factors and the primary and secondary mortgage markets. Regional Science and Urban Economics 30 (6): 683-701.

Ambrose, B., A. Pennington-Cross, and A. Yezer. 2002. Credit rationing in the U.S. mortgage market: Evidence from variation in FHA market shares. Journal of Urban Economics 51 (2): 272-94.

An, X., and R. Bostic. 2008. GSE activity, FHA feedback, and implications for the efficacy of the affordable housing goals. Journal of Real Estate Finance and Economics 36 (2): 207-31.

An, X., R. W. Bostic, Y. Deng, and S. A. Gabriel. 2007. GSE loan purchases, the FHA, and housing outcomes in targeted, low-income neighborhoods. In Brookings-Wharton Papers on Urban Affairs: 2007, ed. G. Burtless and J. R. Pack, 205-40. Washington, DC: Brookings Institution.

Blinder, A., M. Flannery, and J. Kamihachi. 2004. The value of housing-related government sponsored enterprises: A review of a preliminary draft paper by Wayne Passmore. Fannie Mae Papers 3 (2).

Congressional Budget Office (CBO). 2001. Federal subsidies and the housing GSES. Washington, DC: Government Printing Office (GPO).

-2003. Subsidy estimate for FHA mortgage guarantee. Washington, DC: GPO. 2004. Updated estimates of the subsidies to the housing GSES. Washington, DC: GPO.

2006. Assessing the government's costs for mortgage insurance provide by the Federal Housing Administration. Washington, DC: GPO.

Green, R., and S. Wachter. 2005. The American mortgage in historical and international context. Journal of Economic Perspectives 119 (4): 93-114.

Hermalin, B., and D. Jaffee. 1996. The privatization of Fannie Mae and Freddie Mac: Implications for mortgage industry structure. In Studies on privatizing Fannie Mae and Freddie Mac, ed. US Department of Housing and Urban Development (HUD), 225-302. Washington, DC: HUD.

Inside Mortgage Finance. 2007a. MBA calls for cautious approach to FHA reform, even as new bills tout remedies to program's ills. April 6.

. 2007b. Optimism remains high on FHA reform despite critical HUD IG, GAO Reports. March 23.

Jaffee, D. 2009a. Reforming Fannie and Freddie. Regulation 31 (4): 52-57.

2009b. Monoline Regulations to Control the Systemic Risk Created by Investment Banks and GSEs. The B.E. Journal of Economic Analysis \& Policy 9 (3), Symposium, article 17. Available at http://www.bepress.com/bejeap/vol9/iss3/art17.

Jaffee, D., and J. M. Quigley. 2007. Housing subsidies and homeowners: What role 
for government-sponsored enterprises? Brookings-Wharton Papers on Urban Affairs: 2007, ed. G. Burtless and J. R. Pack, 103-49. Washington, DC: Brookings Institution.

2008. Mortgage guarantee programs and the subprime crisis. California Management Review 51 (1): 117-43.

- 2009. The government sponsored enterprises: Recovering from a failed experiment. Berkeley Program on Housing and Urban Policy Working Paper no. W09-001.

Joint Economic Committee. 2007. Sheltering neighborhoods from the subprime foreclosure storm. Report of the US Congress Joint Economic Committee, April 11.

Morgan, D. P. 2007. Defining and detecting predatory lending. Federal Reserve Bank of New York Staff Report no. 273, January.

Murphy, E. 2007. Subprime mortgages: Primer on current lending and foreclosure issues. Congressional Research Service Report, Order Code RL33930. Washington, DC: CRS.

National Association of Realtors. 2007. Proposed statement on subprime lending. Submitted to the Controller of the Currency, May 7.

Passmore, W., S. M. Sherlund, and G. Burgess. 2005. The effect of housing government-sponsored enterprises on mortgage rates. Real Estate Economics 33 (3): 427-63.

Piskorski, T., and A. Tchistyi. 2007. Optimal mortgage design. Paper presented at the National Bureau of Economic Research (NBER) Real Estate conference. 25 July, Cambridge, Massachusetts.

Quigley, J. M. 1998. The taxation of owner-occupied housing. In The encyclopedia of housing, ed. W. van Vliet, 579-81. Thousand Oaks, CA: Sage Publications.

2006. Federal credit and insurance programs: housing. Federal Reserve Bank of St. Louis Review 88 (4): 281-310.

. 2008. Compensation and incentives in the mortgage business. Economists' Voice 5 (13): 1-3.

Sunstein, C., and R. Thaler. 2003. Libertarian paternalism is not an oxymoron. University of Chicago Law Review 70 (4): 1159-202.

United States Department of Housing and Urban Development (HUD). 1995. An analysis of FHA's single-family insurance program. Washington, DC: HUD.

DC: HUD

United States Department of the Treasury. 2000. Predatory lending. Report no. 3076. Available at: http://www.ustreas.gov/press/releases/report3076.htm.

United States Government Accountability Office (GAO). 2004. Consumer protection: Federal and state agencies face challenges in combating predatory lending. GAO-04-412T. Washington, DC: GAO.

\section{DC: GAO.}

2006a. Alternative mortgage products. GAO-06-1021. Washington, 2006b. National Flood Insurance Program. GAO-07-169. Washington, DC: GAO.

2007a. Federal Housing Administration: Decline in the agency's market share was associated with product and process development of other mortgage market participants. GAO-07-646. Washington, DC: GAO.

. 2007b. Modernization proposals would have program and budget implications and require continued improvements in risk management. GAO-07-708. Washington, DC: GAO.

United States Office of Management and Budget. 2008. Budget of the United States government, analytical perspectives, fiscal year 2009. Washington, DC: GPO. 
Vandell, K. D. 1995. FHA restructuring proposals: Alternatives and implications. Housing Policy Debate 6 (2): 299-393.

Weicher, J. 2006. Commentary. Federal Reserve Bank of St. Louis Review 88 (4): $311-22$.

\section{Comment Susan M. Wachter}

Authors Jaffee and Quigley focus their chapter on an analysis of federal programs that provide insurance and housing credit guarantees. After a description of a variety of federal government programs, including the federally-chartered government sponsored enterprises (GSEs) Fannie Mae and Freddie Mac, they concentrate specifically on the changes and challenges to the mortgage insurance and guarantee programs managed by the Federal Housing Administration (FHA). They offer specific, policy-oriented recommendations to bolster the FHA's declining market share.

After the Great Depression, the FHA pioneered the introduction of the thirty-year self-amortizing fixed rate mortgage, the standard mortgage that prevailed in the United States for decades. The FHA and Fannie Mae, and its predecessor the Home Owners' Loan Corporation (HOLC) - a federal entity - succeeded in reviving a mortgage market then in collapse due to the prevalence of "bullet" loans. After World War II, loans insured by the FHA lost market share to similarly structured nongovernment or "conventional" loans. The FHA's role evolved to serve lower income households who lacked the 10 percent down payment required by the conventional prime market. With the explosion (now implosion) of subprime over the past decade, FHA's market share decreased even further until 2008 when, in response to the collapse of subprime, FHA market share increased to its current 25 percent level. The ongoing subprime mortgage market crisis (similar to the Great Depression, centered on loans that require refinancing at a time when financial markets seize up) makes the role of the FHA newly relevant. ${ }^{1}$

A large segment of the Jaffee and Quigley chapter is devoted to a comprehensive and very useful description of all federal housing programs. The chapter sets out an historical and contextual analysis of the evolution of housing programs over time, pointing to the elimination of supply-side public housing in favor of demand-side housing vouchers. The chapter contrasts this - and other directly funded programs that have lost federal support - with the growth of programs indirectly funded through federal tax expenditures, including the homeowner deduction and the low income

Susan M. Wachter is the Richard B. Worley Professor of Financial Management and professor of real estate and finance at The Wharton School, University of Pennsylvania.

1. For additional discussion on the FHA, see Green and Wachter (2007). 